\title{
Host immune response and variations in the virus genome: pathogenesis of liver damage caused by hepatitis B virus
}

Recent understanding of the mechanisms responsible for liver damage during an infection with hepatitis $B$ virus has changed significantly with the application of molecular biological techniques, the formulation of new concepts for $T$ cell recognition of viral antigens, and experience with orthotopic liver transplantation.

Infection with hepatitis B virus (HBV) is associated with a wide spectrum of liver damage ranging from fulminant acute hepatitis to chronic $\mathrm{HBV}$ carriers with minimal hepatic changes or liver cirrhosis. This variation in liver damage was thought to be due to variations in the intensity of the host immune response to the virus. ${ }^{1}$ From a virological point of view two major subgroups of chronic HBV carriers were identified - HBeAg seropositive with active $\mathrm{HBV}$ replication, and patients seropositive for anti-HBe, characterised by the absence of virus replication. In the early phase of chronic infection HBV carriers are HBeAg seropositive with a high level of virus replication, but with minimal liver damage. ${ }^{2}$ This immunotolerant phase is particularly long in cases with vertical transmission of HBV. With time there is a gradual loss of the immune tolerance to the virus, manifested by the onset of the active phase of chronic HBV infection. Histological examination of the liver shows chronic lobular, chronic persistent or chronic active hepatitis and an increase in serum aminotransferase activity. $\mathrm{HBeAg}$ and HBV-DNA are still present in the serum as markers of ongoing virus replication. The duration of this active phase has an important impact in determining whether a transformation of the normal liver architecture into a liver cirrhosis will follow. The immune pressure is concentrated on hepatocytes supporting HBV replication and eventually may eliminate these cells, leading to seroconversion to anti$\mathrm{HBe}$, undetectable $\mathrm{HBV}$ replication, and no hepatic inflammation.

Recent knowledge has challenged this conventional concept of the immunopathogenesis of HBV related liver diseases. Immunology has made huge conceptual advances. It has been shown that $\mathrm{T}$ lymphocytes do not recognise large protein antigens but small peptide fragments of 8-16 amino acid residues, presented within the groove of an HLA molecule. ${ }^{3}$ The use of the polymerase chain reaction technique, DNA sequencing, and cloning has permitted detailed examination of the virus genome and has shown the existence of a number of genomic variants of $\mathrm{HBV},{ }^{4}$ often existing as a mixture of different strains in a patient with chronic infection. 56 Direct detection of the nucleotide sequence of the virus genome has also shown the persistence of HBV replication in chronic carriers, seropositive for anti-HBe, previously believed to be in the 'non-replicative' phase of chronic HBV infection, which made the serological testing for $\mathrm{HBeAg}$ /anti-HBe irrelevant as a marker of ongoing virus replication. Mutations in the viral genome during chronic infection will result in amino acid alterations in translated proteins and consequently in the viral peptides presented to the immune system. Can a new hypothesis for the mechanisms of HBV and host interactions embrace these new findings?

\section{Immune recognition of viral antigens}

Our early attempts to analyse the interactions of cytotoxic $T$ cells with virus infected hepatocytes were based on the autologous microcytotoxicity assay. ${ }^{78}$ Despite some obvious limitations in this system, it had the great advantage of using fully HLA compatible effector and target cells with naturally processed viral peptides. The results showed that in chronic HBV infection $\mathrm{T}$ cell cytotoxicity is directed to viral nucleocapsid protein ${ }^{7}$ and that $T$ lymphocytes selectively lyse hepatocytes expressing $\mathrm{HBcAg}$, but not hepatocytes with $\mathrm{HBsAg}$ only. ${ }^{8}$ In addition, the results of these in vitro experiments suggested that IgG anti-HBc, bound to hepatocytes expressing $\mathrm{HBcAg}$ can modulate the $\mathrm{T}$ cell attack. ${ }^{8}$ Important evidence for the modulatory role of anti-HBc has also been obtained in vivo in chimpanzees, infected with HBV. ${ }^{9}$

More recently, a transgenic mouse model for hepatitis $B$ surface antigen has been used to study the cytolytic effector $\mathrm{T}$ cells against hepatocytes expressing $\mathrm{HBsAg} .{ }^{10}$ The transgenic mouse lineage expressed non-cytotoxic amounts of the large and major virus envelope proteins in hepatocytes. Spleen cells from a non-transgenic mouse were primed by immunisation with a recombinant vaccinia virus containing $\mathrm{HBV}$ envelope polypeptide. When injected in the HBsAg transgenic mouse, these primed spleen cells caused liver cell necrosis. The hepatocellular injury in this model was transient and this system does not reproduce adequately the wide range of viral protein expression in humans. Pre-S2 viral protein has also been shown to be recognised by cytotoxic $\mathrm{T}$ lymphocytes, isolated from a patient with chronic hepatitis B. ${ }^{11}$ The strong correlation, however, between ongoing HBV replication with $\mathrm{HBcAg}$ in hepatocytes and the persistent inflammatory activity in the liver has established the nucleocapsid protein of $\mathrm{HBV}-\mathrm{HBcAg}$ as the main focus in HBV/host interactions both with respect to the pathogenesis of liver cell necrosis and the clearance of infected hepatocytes. Nucleocapsid proteins have also been shown to be important targets for the cytotoxic $T$ lymphocyte response against several other viruses. ${ }^{12-14}$

HBV nucleocapsid (HBcAg) and its secretable, non-particulate form ( $\mathrm{HBeAg}$ ) are highly cross reactive at the $\mathrm{T}$ helper cell level. ${ }^{15} 16 \mathrm{HBeAg}$ is a non-structural protein encoded by the precore/core gene of the HBV genome, which is present in the serum of patients, infected with the wild type of HBV. Recently, HBeAg has also been 
shown to be expressed on the cell membrane, ${ }^{17}$ leading to speculation as to whether $\mathrm{HBeAg}$ or $\mathrm{HBcAg}$ is the target for the cytotoxic $T$ cell response at different phases of chronic HBV infection. The fundamental concept of $T$ cell recognition is that $T$ lymphocytes, whether helper or cytotoxic, recognise small peptide fragments of about 8-16 amino acids in length, which are presented to the antigen receptor of HLA compatible T cells in a special groove on the top of an HLA antigen. ${ }^{3}$ Cytotoxic $T$ cells use their surface CD8 molecule to probe for a corresponding epitope on the side of the class I HLA molecule and their antigen receptor to probe for a complementary antigenic peptide in the groove and this complex will then trigger the cytolytic process. Similarly, helper T cells probably use CD4 molecules to search for HLA class II molecules on the antigen presenting cell. The presence of an antigenic peptide in the groove, complementary to the helper $\mathrm{T}$ cell antigen receptor will then trigger the release of cytokines. Thus, although serologically distinct, $\mathrm{HBcAg}$ and $\mathrm{HBeAg}$ share a substantial aminoacid homology and are not different in respect to $T$ cells, to which only small peptide fragments are presented. In this context, viral peptides expressed within the groove of an HLA molecule on the surface of infected hepatocytes will not be detectable by antibodies. Thus, viral antigens - $\mathrm{HBcAg}, \mathrm{HBeAg}$, and HBsAg-detectable on the hepatocyte membrane using monoclonal or polyclonal antibodies are probably not being displayed in HLA molecules and therefore not recognisable by the host $\mathrm{T}$ lymphocytes.

Both CD4 and CD8 positive $T$ cells, specific for $\mathrm{HBcAg}$, have been isolated from liver specimens from patients with chronic hepatitis $\mathrm{B}$. These $\mathrm{T}$ cells produced and secreted several cytokines including interleukin 2, interferon gamma, and tumour necrosis factor. ${ }^{18} \mathrm{CD} 4$ cells in the peripheral blood show a strong proliferative response to $\mathrm{HBcAg}$ or to $\mathrm{HBeAg}$ in patients with acute hepatitis B. ${ }^{19}$ During the exacerbations of hepatitis in chronic HBV carriers peripheral blood $\mathrm{T}$ cells show an increased proliferative response to $\mathrm{HBcAg}$ as well as increased production of interferon gamma. ${ }^{20}$ These data suggest that $\mathrm{HBcAg}$ specific $\mathrm{CD} 4$ positive, $\mathrm{T}$ helper cells may also participate in the pathogenesis of liver damage in HBV infection. The correlation between the helper $T$ cell response to $\mathrm{HBcAg}$ and $\mathrm{HBV}$ clearance in patients with acute hepatitis $B$ may be explained by the requirement of a helper $\mathrm{T}$ cell function for the induction of $\mathrm{HBcAg}$ specific cytotoxic $\mathrm{T}$ lymphocyte response or the effect of cytokines released from CD4 cells. The potential importance of the HBV nucleocapsid protein as a target for the host immune response in $\mathrm{HBV}$ infection is emphasised by the fact that $\mathrm{HBcAg}$ is about 100 -fold more immunogenic in comparison with HBsAg at both the $T$ cell and the $B$ cell level. ${ }^{21}$ In addition, HBcAg specific $T$ helper cells can elicit the production of anti-HBs antibody by $\mathrm{B}$ cells, specific for the HBV envelope antigen when stimulated by virions. ${ }^{22}$

Using a mouse model, Milich et al have analysed the fine specificity of $T$ lymphocyte recognition of the nucleocapsid protein. ${ }^{16} \mathrm{HBcAg}$ specific $\mathrm{T}$ cells from a variety of murine strains recognised multiple, but distinct 12 to 21 peptide fragments within the $\mathrm{HBcAg} / \mathrm{HBeAg}$ sequence. Most importantly, although several strains recognised multiple sites, each strain was found to recognise a predominant $T$ cell epitope and the fine specificity of this determinant was dependent on the $\mathrm{H}-2$ haplotype of that particular strain.

In a series of experiments C Ferrari et al from Parma, in collaboration with $\mathrm{F}$ Chisari in $\mathrm{La}$ Jolla, California analysed the fine specificity of cytotoxic $T$ cell epitopes of $\mathrm{HBV}$ nucleocapsid protein in patients with acute hepatitis B. ${ }^{23-26}$ So far, two epitopes for CD8 positive cytotoxic $\mathrm{T}$ lymphocyte have been identified on $\mathrm{HBcAg}$ - an epitope located between amino acid residues 18-27 from the beginning of the nucleocapsid protein, which is HLA-A2 restricted and an epitope between residues 141-151, which is dually restricted by HLA-A31 and HLA-AW68. In addition, it has been shown that the $\mathrm{HBcAg}$ specific cytotoxic T lymphocyte response in acute, self limiting hepatitis B is directed to multiple viral epitopes - that is, it is polyclonal and multispecific. ${ }^{26}$ In stable chronic hepatitis B it was not possible to show the cytotoxic $T$ lymphocyte response, suggesting one possible defect to permit virus persistence in these patients. In the studies in acute hepatitis B it was shown that endogenously synthesised precore and core proteins are equally good targets for the nucleocapsid cytotoxic $T$ lymphocyte response to a shared epitope 141-151, similar to the shared 18-27, thus implying that the HBV variant with a precore stop codon mutation, is unlikely to arise as a cytotoxic $\mathrm{T}$ lymphocyte escape mutant, as hepatocytes infected by this strain will still produce core protein and express the cytotoxic $\mathrm{T}$ lymphocyte epitope 141-151. At present, it is unknown whether the peptides expressed on the surface of hepatocytes infected with a wild type HBV differ from the peptides presented on the surface of hepatocytes, infected with the $\mathrm{HBe}$ minus variant of the virus. Proteins that are present in different cellular compartments $(\mathrm{HBeAg}$ in the membranes of endoplasmic reticulum and particulate $\mathrm{HBcAg}$ in the cytosol) may be processed differently and result in different peptides being inserted into the HLA groove.

Thus, recent data support the notion that helper and cytotoxic $\mathrm{T}$ lymphocyte response to $\mathrm{HBV}$ antigens and $\mathrm{HBcAg}$ in particular, play an important part in the pathogenesis of liver cell necrosis and for viral clearance in HBV infection.

\section{Variations in the virus genome - the chicken or the egg in chronic active hepatitis $B$}

Molecular cloning and nucleotide sequencing have clearly established the organisation of the HBV genome and its four open reading frames. ${ }^{27}$ Wider application of the molecular biological techniques to clinical samples showed considerable variation and heterogeneity in the virus population among different patients with chronic $\mathrm{HBV}$ infection, as well as during different phases of this infection, thus emphasising variations in the HBV genome as another important determinant in the pathogenesis of liver damage.

An HBV variant with a point mutation at position 1896 ( $G$ to A substitution) of the precore region has been identified, which creates a stop codon and hampers the translation of $\mathrm{HBeAg} .{ }^{28} 29$ As translation from the second start codon in the core gene is possible, $\mathrm{HBcAg}$ can be produced and this mutation thus does not interfere with virus replication. After the initial description, this precore mutant type of HBV was thought to be associated with severe liver damage in chronic hepatitis B seropositive for anti-HBe, and in patients with acute fulminant hepatitis B. ${ }^{30-33}$ We studied the nucleotide sequence of the HBV precore region in 29 patients, seropositive for anti-HBe, with a wide spectrum of underlying liver damage to analyse the pathogenicity of this mutant variant and its relation to liver disease. ${ }^{5} \mathrm{HBV}$ variants with a precore stop codon were found both in patients without hepatic inflammation, as well as in those with chronic active hepatitis. The fact that the precore stop codon $\mathrm{A}_{1896} \mathrm{HBV}$ is not invariably pathogenic was subsequently confirmed. This mutant strain emerges during seroconversion to anti- $\mathrm{HBe}$ in patients treated with interferon and is also detectable in 
asymptomatic HBsAg, anti-HBe seropositive blood donors without evidence of liver damage. ${ }^{34} 35$

In about $20 \%$ of cases with recurrent HBV infection in a liver transplant a novel syndrome has been described, fibrosing cholestatic hepatitis, characterised by serpiginous liver fibrosis, severe cholestasis, massive expression of viral proteins in hepatocytes, and progressive liver failure. ${ }^{36-38}$ The pathogenesis of liver cell necrosis in this syndrome is probably due to a direct cytotoxic effect of $\mathrm{HBV}$, as there is minimal inflammatory reaction in the liver. To analyse the impact of $\mathrm{HBV}$ mutants in the development of this syndrome, 11 patients with $\mathrm{HBV}$ recurrence in the graft, six of whom progressed to fibrosing cholestatic hepatitis, have been studied at the Institute of Liver Studies. ${ }^{39}$ The results showed that the presence of precore stop codon $\mathrm{A}_{1896} \mathrm{HBV}$ was not associated with the development of this syndrome, while multiple mutations in the core gene, resulting in considerable amino acid alterations in viral nucleocapsid have been identified only in those patients who developed fibrosing cholestatic hepatitis.

Which other factors are then involved in determining the degree of liver damage in $\mathrm{HBV}$ infection with predominant $\mathrm{A}_{1896} \mathrm{HBV}$ variant? The level of virus replication seems one of them, as we and others have found that the hepatic injury in anti-HBe positive chronic hepatitis B correlates with the serum HBV-DNA concentration. ${ }^{540}$ Two other findings lend further support to this relation. In a liver transplant recipient with severe recurrence of precore mutant HBV infection, progressive increase of viraemia led to fibrosing cholestatic hepatitis five months after transplantation. ${ }^{41}$ Effective inhibition of precore mutant HBV replication with nucleoside analogues in this patient resulted in a dramatic improvement of liver function and liver histology tests, while in another study, reactivation of the precore mutant $\mathrm{HBV}$, after withdrawal of cytotoxic treatment in anti-HBe positive healthy carriers resulted in a high level of virus replication and led to fulminant hepatic failure. ${ }^{42}$ This positive relation between the level of virus replication and the degree of liver damage in anti$\mathrm{HBe}$ positive chronic hepatitis $B$ contrasts with the findings in $\mathrm{HBeAg}$ seropositive carriers in whom there is an inverse relation between serum HBV-DNA concentration and the degree of liver cell necrosis. ${ }^{243} \mathrm{HBeAg}$ plays an important immunomodulatory part, which may explain this difference between $\mathrm{HBeAg}(+)$ and anti-HBe(+) chronic hepatitis. ${ }^{44} \mathrm{~A}$ recent study in woodchucks has shown that after the inoculation of a wild type HBV or a precore mutant HBV strain in neonatal animals both virus strains have a comparable level of replication, but none of the five woodchucks infected with the precore mutant virus as neonates became chronic virus carriers. ${ }^{45}$

Mutations in the virus genome outside the precore region of the same $\mathrm{HBV}$ strain must also be considered, as they may play a significant part in changing virus-host interactions. A recent in vitro study compared the replication of wild type $\mathrm{HBV}$, the same strain with an introduced precore stop codon, and an HBV strain, isolated from a patient with fulminant hepatitis, which in addition to the precore stop codon had numerous mutations in other parts of the genome. ${ }^{46}$ The fulminant HBV strain showed much higher replication as well as a higher level of intracellular accumulation of $\mathrm{HBcAg}$ in comparison with the other two strains, which had similar replicative capacity. These data show convincingly that the precore stop codon in itself is not the cause of a more pathogenic HBV variant. Instead, higher replicative capacity and higher antigen expression, induced by other mutations in an HBV type with a precore stop codon may be the cause of the severe liver damage. A temporal relation between clustering missense mutations in the core gene of $\mathrm{HBV}$ and the $\mathrm{A}_{1896}$ stop codon mutation in the precore region has been noted in patients with chronic hepatitis $\mathrm{B} .{ }^{47}$

Several studies have shown that patients with chronic active hepatitis B are often carrying $\mathrm{HBV}$ variants with mutations in the core gene, which are not present in $\mathrm{HBeAg}(+)$ carriers who despite the ongoing virus replication have minimal hepatic changes. ${ }^{64-50}$ In a study from Japan, as well as from our Institute, large deletions in the middle of the core gene were identified and the deleted area among different clones of the virus was remarkably consistent between codons 80-110 from the start of the core gene. ${ }^{648}$ The number of deleted bases was often a multiple of 3 , suggesting that a core protein could be translated and this variant core peptide is probably both immunologically and functionally different from the full length nucleocapsid protein. In other reports the observed variations in the core gene were nucleotide substitutions, rather than deletions, but the missense mutations resulting in changes in the deduced aminoacids clustered in particular areas - between codons 84-101 and 48-60 of the core gene. ${ }^{4749}$ Thus, there is a substantial body of evidence that $\mathrm{HBV}$ variants with clustering mutations in the core gene comprise the predominant part of the virus population in patients with chronic active hepatitis.

As these studies analysed the variations in the core gene in a cross sectional aspect, it is uncertain whether these HBV variants are the cause of a more severe liver damage or whether these HBV strains have been left over by the host immune attack. Indeed, these may be escape mutant variants of the virus, accumulated as a result of a positive selection by the host immune response, focused on particular epitopes of the core protein during the inflammatory activity. In an attempt to answer this question Wan Chuang et al sequenced HBV core gene in serial serum samples from two HBV carriers seropositive for $\mathrm{HBeAg}$ and minimal hepatic changes - one of whom progressed to chronic active hepatitis while the clinical course in the other patient was uneventful. ${ }^{51} \mathrm{HBV}$ strains with missense mutations in the core gene were cloned from the former patient at a comparatively early phase of raised serum aminotransferases but the same strains were not found in the serum samples at the time of most severe liver damage. This was associated with concentrating point mutations between codons 84-101. In contrast, no missense mutations were found in the other patient who remained asymptomatic. The fact that liver damage in HBV infection is not related only to a particular virus strain is emphasised by the finding that an identical HBV type with no changes in the precore and with multiple mutations in the core gene, was isolated from a patient with fulminant hepatitis, as well as from the sexual partner who had chronic active hepatitis B. ${ }^{50}$

The accumulation of HBV variants with precore/core gene mutations may change virus - host interactions in several aspects. Firstly, the peptides derived from the virus nucleocapsid presented within HLA molecules on the surface of hepatocytes will have a different composition and may trigger new sequences of $T$ cell reactions. Secondly, mutations may affect the intracellular transport or packing of the core particles. It is known from earlier studies that there is an increased cytoplasmic and membranous expression of core protein in $\mathrm{HBsAg}$ positive patients with active hepatitis. ${ }^{52} 53$ While the activation of cytotoxic $T$ lymphocytes is believed to require the expression of no more than 100 viral peptides, the lysis of infected cells by antibodies require much stronger expression of the target antigen. ${ }^{125455}$ Thus, the enhanced expression of $\mathrm{HBcAg}$ in chronic active hepatitis may involve other immune mechanisms in addition to the cytotoxic $\mathrm{T}$ lymphocyte response, for example antibody dependent cytotoxicity or 
cytokine release, or both which will also contribute to the progression of liver damage. Thirdly, some of the newly emerging HBV strains may have direct cytopathic effects on the infected cells or the accumulation of unenveloped core particles could be damaging to hepatocytes. Supporting evidence comes from in vitro studies using HBV transfected liver cells in culture. In HepG2 cells, non-productive $\mathrm{HBV}$ infection was associated with accumulation of core protein and direct cytopathic effect. ${ }^{56}$

In conclusion, current data suggest that two closely related factors - the characteristics of the virus population and the repertoire of the host immune response - will determine the outcome of the infection with HBV. A prompt polyclonal and multispecific response by the $T$ lymphocytes - entailing both the cytotoxic and the helper T cells - will clear the virus in an acute self limiting hepatitis B. In some subjects infection with wild type HBV will become chronic as a result of a less efficient immune response and virus replication will continue with minimal liver damage. The precore region of the virus genome is highly conserved both in human and in woodchuck hepatitis virus. $\mathrm{HBeAg}$ encoded by this region and secreted in the circulation may act as an active mechanism for inducing immune tolerance. A gradual loss of immune tolerance occurs with time in $\mathrm{HBeAg}$ seropositive patients, but it is of limited clonality, thus permitting viral mutations to evade this limited response. It is possible, however, that mutants arise spontaneously because of errors in virus replication and this could trigger loss of tolerance as modified target peptides will be presented to the immune system.

During the HBeAg positive phase, those B lymphocytes that can bind HBeAg through their surface immunoglobulin will internalise this antigen and present on their cell surface the relevant peptides, derived from the proteolytic cleavage of $\mathrm{HBeAg}$, in the groove of HLA class II molecules. While tolerance is maintained, $T$ helper cells cannot signal the humoral or the cellular effector arms of the immune response by secreting interleukin 4 , interferon gamma, etc. Therefore, the loss of helper $\mathrm{T}$ cell tolerance would not only be a fundamental factor in mounting the immune attack to $\mathrm{HBV}$ and a pivotal point during the course of chronic HBV infection, but would also provide the $T$ cell help to permit $B$ lymphocytes to produce antibody to circulating $\mathrm{HBeAg}$. Indeed, $\mathrm{HBeAg} / \mathrm{anti}-\mathrm{HBe}$ immune complexes have been detected in chronic HBV carriers. ${ }^{57}$ The immune pressure against $\mathrm{HBeAg}$ and a successful $T$ cell attack against hepatocytes expressing HBV nucleocapsid peptides may lead to elimination of virus replication and cessation of liver damage. In some patients, however, the production of anti-HBe antibody may lead to the selection of HBV strains with mutations in the precore region, which will prevent the translation of HBeAg, the commonest of which is the $A_{1896}$ precore stop codon. The lack of $\mathrm{HBeAg}$ and the release in the circulation of a particulate $\mathrm{HBcAg}$ from damaged hepatocytes will then accelerate the loss of immune tolerance to nucleocapsid peptides. The longer the duration of the inflammatory activity in the liver, the more genomic variations will accumulate in the dominant $\mathrm{HBV}$ strain or viral quasispecies will evolve in the individual patient. During this process HBV strains with mutations, which permit them to escape the immune pressure will be selected and will maintain chronic virus infection. Some HBV strains with point mutations or deletions may have direct cytotoxic effects on infected hepatocytes. Genomic variations may also affect the replicative potential of the virus and a selection of strains replicating at high level will cause exacerbation of hepatitis in a chronic HBV carrier. If such $\mathrm{HBe}$ minus variants with high replicative potential are transmitted from a chronic carrier to a new host, whose $T$ cell response is not impaired and there is no secretable tolerogen like $\mathrm{HBeAg}$, liver damage may be severe and could present clinically as acute fulminant hepatitis.

N V NAOUMOV

Institute of Liver Studies,

A L W F EDDLESTON

King's College School of Medicine and Dentistry,

Bessemer Road,

London SE5 9PF

1 Mondelli M, Eddleston ALWF. Mechanisms of liver cell injury in acute and chronic hepatitis B. Semin Liver Dis 1984; 4: 47-58.

2 Chu C-M, Karayiannis P, Fowler MJF, Monjardino J, Liaw Y-F, Thomas HC. Natural history of chronic hepatitis B virus infection in Taiwan: studies of hepatitis B virus DNA in serum. Hepatology 1985; 5: 431-4.

studies of hepatitis B virus DNA in serum. Hepatology 1985; 5: 431-4.
Kourilsky P, Claverie JM. MHC antigen interaction: what does the T cell ourilsky P, Claverie JM. MHC antigen interact
receptor see? Adv Immunol 1989; 45: 107-94.

4 Carman WF, Thomas HC. Genetic variation in hepatitis B virus. Gastroenterology 1992; 102: 711-9.

5 Naoumov NV, Schneider R, Grotzinger T, Jung MC, Miska S, Pape GR, et al. Precore mutant hepatitis $\mathbf{B}$ virus infection and liver disease. Gastroenterology 1992; 102: 538-43.

6 Ackrill AM, Naoumov NV, Eddleston ALWF, Williams R. Specific deletions in the hepatitis B virus core open reading frame in patients with chronic active hepatitis B. $\mathcal{F}$ Med Virol 1993; 41: 165-9.

7 Mondelli M, Mieli-Vergani G, Alberti A, Vergani D, Portmann B, Eddleston ALWF, et al. Specificity of T lymphocyte cytotoxicity to Eddeston ALWF, et al. Specificity of autologous hepatocytes in chronic hepatitis $\mathrm{B}$ virus infection: evidence that Tells are directed against HBV

8 Naoumov NV, Mondelli M, Alexander GJM, Tedder RS, Eddleston AL, Williams R. Relationship between expression of hepatitis $B$ virus antigens in isolated hepatocytes and autologous lymphocyte cytotoxicity in patients with chronic hepatitis B virus infection. Hepatology 1984; 4: 63-8.

9 Pignatelli M, Waters J, Lever A, Iwarson S, Gerety R, Thomas HC. Cytotoxic $T$ cell responses to the nucleocapsid proteins of $\mathrm{HBV}$ in chronic hepatitis. Evidence that antibody modulation may cause protracted infection. $\mathcal{F}$ Hepatol 1987; 4: 15-21.

10 Moriyama T, Guilhot S, Klopchin K, Moss B, Pinkert CA, Palmiter RD, et al. Immunobiology and pathogenesis of hepatocellular injury in hepatitis B virus transgenic mice. Science 1990; 248: 361-4.

11 Barnaba V, Franco A, Alberti A, Balsano C, Venvenutto R, Balsano F. Recognition of hepatitis $B$ virus envelope proteins by liver infiltrating $T$ lymphocytes in chronic HBV infection. F Immunol 1989; 143: 2650-5.

12 Townsend ARM, Rothbard J, Gotch FM, Bahadur G, Wraith D, McMichael AJ. The epitopes of influenza nucleoprotein recognised by cytotoxic T lymphocytes can be defined with short synthetic peptides. Cell 1986; 44: 959

13 Nixon DF, Townsend ARM, Elvin JG, Rizza CR, Gallwey J, McMachael AJ. HIV-1 gag-specific cytotoxic T lymphocytes defined with recombinant vaccinia virus and synthetic peptides. Nature 1988; 336: 484.

14 Bangham CRM, Openshaw PJM, Ball LA, King AMQ, Wertz GW, Askonas BA. Human and murine cytotoxic T cells specific to respiratory syncytial virus recognize the viral nucleoprotein $(N)$ but not the major glycoprotein $(G)$, expressed by vaccinia virus recombinants. I Immunol 1986; 137: 3973.

15 Milich DR, McLachlan A. The nucleocapsid of hepatitis B virus is both a T-cell independent and T-cell dependent antigen. Science 1986; 234: 1398-401.

16 Milich DR, McLachlan A, Moriarty A, Thornton GB. The immune response to the hepatitis B core antigen ( $\mathrm{HBcAg}$ ): localization of $T$ cell recognition sites within $\mathrm{HBcAg} / \mathrm{HBeAg}$. F Immunol 1987; 139: 1223-32. 7 Schlicht H-J, Schaller $H$. The secretory core protein of human hepatitis B virus is expressed on the cell surface. $\mathcal{F}$ Virol 1989 ; 63: 5399-404.

18 Ferrari C, Penna A, Giuberti T, Tong MJ, Ribera E, Fiaccadori F, et al. Intrahepatic nucleocapsid antigen specific $\mathrm{T}$ cells in chronic active hepatitis B. F Immunol 1987; 139: 2050-60.

19 Ferrari C, Penna A, Bertoletti A, Valli A, Antoni AD, Giuberti T, et al. Cellular immune response to hepatitis $\mathbf{B}$ virus encoded antigens in acute and chronic hepatitis B virus infection. F Immunol 1990; 145: 3442-9.

20 Inoue $M$, Kakumu $S$, Yoshioka $K$, Tsutsumi $Y$, Wakita $T$, Arao $M$. Hepatitis B core antigen specific IFN-gamma production of peripheral blood mononuclear cells in patients with chronic hepatitis B virus blood mononuclear cells in patients with
infection. F Immunol 1989; 142: 4006-16.

21 Milich DR, Louie RE, Chisari FV. Genetic regulation of the immune response to hepatitis $B$ surface antigen (HBsAg). $T$ cell proliferative response and cellular interactions. F Immunol 1985; 134: 4194-202.

22 Milich DR, McLachlan A, Thornton GB, Hughes JL. Antibody production to the nucleocapsid and envelope of the hepatitis $B$ virus primed by a single synthetic $T$ cell site. Nature 1987 ; 329: 547-9.

23 Penna A, Chisari FV, Bertoletti A, Missale G, Fowler P, Giuberti T, et al. Cytotoxic T lymphocytes recognise an HLA-A2 restricted epitope within the hepatitis B virus nucleocapsid antigen. F Exp Med 1991; 174: 1565.

24 Ferrari C, Bertolleti A, Penna A, Cavalli A, Valli A, Missale G, et al. Identification of immunodominant $T$ cell epitopes of the hepatitis $B$ virus nucleocapsid antigen. $\mathcal{F}$ Clin Invest 1991; 88: 214-22.

25 Bertoletti A, Chisari FV, Penna A, Guilhot S, Galati L, Missale G, et al. Definition of a minimal optimal cytotoxic $T$ cell epitope within the hepatitis B virus nucleocapsid protein. 3 Virol 1993; 67: 2376-80.

26 Missale G, Redeker A, Person J, Fowler P. Guilhot S, Schlicht HJ, et al. HLA-A31 and HLA-AW68 restricted cytotoxic T cell responses to a HLA-A31 and HLA-AW 68 restricted cytotoxic T cell responses to a
single hepatitis B virus nucleocapsid epitope during acute viral hepatitis. single hepatitis B virus nucleocap

$27 \mathrm{Lau}$ IYN, Wright TL. Molecular virology and pathogenesis of hepatitis B. Lancet 1993; 342: 1335-40.

28 Carman WF, Jacyna MR, Hadziyannis S, Karayannis P, McGarvey MJ, Makris A, et al. Mutation preventing formation of hepatitis $B$ e antigen in patients with chronic hepatitis B infection. Lancet 1989; ii: 588-91. 
29 Brunetto MR, Stemler M, Bonino F, Schodel F, Oliveri F, Rizzeto M, et al. A new hepatitis $B$ virus strain in patients with severe anti-HBe positive chronic hepatitis. f Hepatol 1990; 10: 258-61.

30 Omata M, Ehata T, Yokosuka O, Hosoda K, Ohto M. Mutations in the precore region of hepatitis $B$ virus DNA in patients with fulminan hepatitis and severe hepatitis. N Engl f Med 1991; 324: 1699-704.

31 Carman WF, Fagan EA, Hadziyannis S, Karayiannis P, Tassopoulos NC Williams $\mathbf{R}$, et al. Association of a precore genomic variant of hepatitis $B$ virus with fulminant hepatitis. Hepatology 1991; 14: 319-22.

32 Kosaka Y, Takase K, Kojima M, Shimizu M, Inoue K, Yoshiba M, et al. Fulminant hepatitis $B$ : induction by hepatitis $B$ virus mutants defective in Fulminant hepatitis B: induction by hepatitis B virus mutants defective in the precore region and
1991; 100: $1087-94$.

33 Brunetto MR, Giarin MM, Oliveri F, Chiaberge E, Baldi M, Alfarano A et al. Wild type and e antigen-minus hepatitis viruses and course of chronic hepatitis. Proc Natl Acad Sci USA 1991; 88: 4186-90.

34 Gunther S, Meisel H, Reip A, Miska S, Kruger DH, Will H. Frequent and rapid emergence of mutated pre-C sequences in HBV from e-antigen positive carriers who seroconvert to anti-HBe during interferon treatment. Virology 1992; 187: 271-9.

35 Tur-Kaspa $R$, Klein A, Aharonson $S$. Hepatitis $B$ virus precore mutants are identical in carriers from various ethnic origins and are associated with a range of liver disease severity. Hepatology 1992; 16: 1338-42.

36 Davies SE, Portmann B, O'Grady J, Aldis PM, Chaggar K, Alexander GJM, et al. Hepatic histology following transplantation for chronic hepatitis B infection including a unique pattern of fibrosing cholestatic hepatitis. Hepatology 1991; 13: 150-7.

37 O'Grady J, Smith HM, Davies S, Daniels HM, Donaldson PT, Tan KC, et al. Hepatitis B virus reinfection after orthotopic liver transplantation. f Hepatol 1992; 14: 104-11.

38 Lau JYN, Davies S, Bain VG, O'Grady JG, Alberti A, Alexander GJM, et al. High level expression of hepatitis B viral antigens in fibrosing cholestatic hepatitis. Gastroenterology 1992; 102: 956-62.

39 Ackrill AM, Naoumov NV, Lau JYN, O'Grady J, Portmann B, Eddleston ALWF, et al. Molecular changes in hepatitis B virus (HBV) core gene in liver raft recipients and association with fibrosing cholestatic hepatitis (FCH). Hepatology 1992; 16: 49A.

40 Mangia A, Hoofnagle JH, Di Bisceglie AM. Serum HBV DNA levels correlate with the presence of hepatic injury in patients with chronic correlate with the presence of hepatic injury in patients with
hepatitis B seronegative for $\mathrm{HBeAg}$. Hepatology 1993; 18: 115A.

41 Angus $\mathrm{P}$, Richards M, Bowden S, Ireton J, Sinclair R, Jones R, et al. Combination antiviral therapy controls severe post liver transplant recurrence of hepatitis B virus infection. $\mathcal{f}$ Gastroenterol Hepatol 1993; 8: 353-7.

42 Yoshiba M, Sekiyama K, Sugata F, Okamoto H, Yamamoto K, Yotsumotot S. Reactivation of precore mutant hepatitis B virus leading to 37: 1253-9.

43 Alberti A, Tremolada F, Fattovich G, Bortolotti F, Realdi G. Virus replication and liver disease in chronic hepatitis B virus infection. Dig Dis Sci 1983; 28: 962-6.

44 Milich DR, Jones JE, Hughes JL, Price J, Raney AK, McLachlan A. Is a function of the secreted hepatitis $B$ e antigen to induce immunologic tolerance in utero? Proc Natl Acad Sci USA 1990; 87: 6599-603.

45 Chen HS, Kew MC, Hornbuckle WE, Tennant BC, Cote PJ, Gerin JL, et al. The precore gene of the woodchuck hepatitis virus genome is not et al. The precore gene of the woodchuck hepatitis virus genome is

46 Hasegawa K, Huang JK, Liang TJ. Enhanced viral replication of a hepatitis $B$ virus mutant associated with an epidemic of fulminant hepatitis. Hepatology 1993; 18: 145A

47 Chuang W-L, Omata M, Ehata T, Yokosuka O, Ito Y, Imazeki F, et al. Precore mutations and core clustering mutations in chronic hepatitis B virus infection. Gastroenterology 1993; 104: 263-71.

48 Wakita T, Kakumu S, Shibata M, Yoshioka K, Ito Y, Shinagawa T, et al. Detection of pre-c and core region mutants of hepatitis $\mathrm{B}$ virus in chronic hepatitis B virus carriers. $\mathcal{F}$ Clin Invest 1991; 88: 1793-801.

49 Ehata $T$, Omata $M$, Yokosuka O, Hosoda $K$, Ohto $M$. Variations in codons $84-101$ in the core nucleotide sequence correlate with hepatocellular injury in chronic hepatitis B virus infection. $\mathcal{F}$ Clin Invest 1992; 89: 332-8.

50 Ehata T, Omata M, Chuang W-L, Yokosuka O, Ito Y, Hosoda K, et al. Mutations in core nucleotide sequence of hepatitis $\mathrm{B}$ virus correlate with fulminant and severe hepatitis. $\mathcal{F}$ Clin Invest 1993; 91: 1206-13.

51 Chuang W-L, Omata M, Ehata T, Yokosuka O, Ohto M. Concentrating missense mutations in core gene of hepatitis B virus. Dig Dis Sci 1993; 38: 594-600.

52 Hsu HC, Su IJ, Mai MY, et al. Biologic and prognostic significance of hepatocyte hepatitis B core antigen expression in the natural course of chronic hepatitis B virus infection. $\mathcal{F}$ Hepatol 1987; 5: 45-50.

53 Naoumov NV, Portmann BC, Tedder RS, Ferns B, Eddleston ALWF, Williams R. Detection of hepatitis B virus antigens in liver tissue. A relation to viral replication and histology in chronic hepatitis B infection. Gastroenterology 1990; 99: 1248-53.

54 Demotz S, Grey HM, Sette A. The minimal number of class II MHCantigen complexes needed for $T$ cell activation. Science 1990; 249: 1028-30.

55 Oldstone MBA. Molecular anatomy of viral persistence. 7 Virol 1991; 65: 6381-6.

56 Roingeard P, Romet-Lemonne J-L, Leturcq D, Goudeau A, Essex M. Hepatitis $B$ virus core antigen ( $\mathrm{HBcAg}$ ) accumulation in an $\mathrm{HBV}$ nonproducer clone of HepG2 transfected cells is associated with cytopathic effect. Virology 1990; 179: 113-20.

57 Castillo I, Bartolome J, Quiroga JA, Porres JC, Carreno V. Detection of $\mathrm{HBeAg} /$ anti-HBe immune complexes in the reactivation of hepatitis B virus replication among anti-HBe chronic carriers. Liver 1990; 10: $79-84$. 